\title{
[1. X 線光学]
}

\section{全反射結像系}

筑波大学・物理工学系 坂 柳 義 巳

\section{1. はじめに}

“X線にはレンズが無いから…..” といら言葉がしばしばX線の本に現われてくる。たし かに，X線領域では光学レンズに匹敵する都合のよいものはないでしょら。しかし，だから 即結像系がないと早合点するのも気がはやすぎる，X線にはブラグ反射もあり，また全反射 もおこる.これらを上手に利用すれば色々な光学系を作ることができ, 結像系も作ることが 可能である．ピンホールや影絵だけを利用するのがX線の宿命のように考える必要はないで しょら．ただ,このような光学系を作ることは簡単ではない.光学レンズが精度よく作れる のは球面が精度よく研磨できるからで, 球面からずれた面, 即ち非球面の研磨はむつかしい. X線光学系も球面で近似して精度がよければよいが，斜入射を用いると球面では不充分で， どらしても非球面が必要となる，そのため製作がむつかしくなるまた，このよらにして作 ったX線光学系も光のレンズとくらべると明るさなどは劣る.しかし，ピンホールとくらべ ると格段に明るいものとなる.

\section{X線の全反射}

X線が空気中より平面に斜に入射すると全反射される. 即ち屈折率が 1 より僅かに小さい. 屈折率を $n$ とすると, 次式で表わされる.

$$
\begin{array}{ll}
n=1-\delta=1-\delta^{\prime} \lambda^{2} \\
\quad \text { ここで } \quad \delta^{\prime}=\frac{\rho^{\prime}}{2 \pi} \gamma_{e} \\
\rho^{\prime}: 1 \mathrm{cc} \text { 中の自由電子の数 } \\
\gamma_{e}: \text { 電子の古典半径 }=2.7188 \times 10^{-13} \mathrm{~cm} \\
\lambda: \text { 波長 }(\mathrm{cm})
\end{array}
$$

ガラスを $\mathrm{SiO}_{2}$ とし， $\mathrm{L}, \mathrm{M}$ 電子を自由電子と考えると， 1 分子中の自由電子の数は 24 , ガ ラスの比重を 2.5 とすると,

$$
\rho^{\prime}=\frac{2.5}{60} \times 24 \times 6 \times 10^{23}=6 \times 10^{23}
$$

$8 \AA ̊$ のX線に対する屈折率 $n$ は

$$
n=1-\delta=1-1.73 \times 10^{-4}
$$

全反射の臨界角を $\theta_{c}$ とする $\left(\theta_{c}\right.$ は面から測る）と,

$$
\begin{gathered}
1-\delta=n=\cos \theta_{c}=1-\frac{\theta_{c}{ }^{2}}{2} \\
\therefore \quad \theta_{c}=\sqrt{2 \delta}=\sqrt{2{\delta^{\prime}}^{\prime}} \cdot \lambda=18.6 \times 10^{-3}
\end{gathered}
$$


ガラスに対して $\mathrm{AlK} \alpha$ の臨界角を $19 \mathrm{~m} \operatorname{rad}$ と考えてよい。

光学系を考えるときにはすべての光線に対して視斜角が $\theta_{c}$ より小さくなくてはならない. 光束は開き角をもっているから，ガラスに対して中心光線の入射角を $15 \mathrm{~m} \mathrm{rad}$ 位にとるの が安全である.

\section{3. $\mathbf{X}$ 線結像光学系}

点を点に結像する光学系を考えるには軸対称の系を考えるのがよい. 光学の結像理論から， もし系が正弦条件 (sine condition) を満たすと, 軸上の結像の性質が分かれば, 軸からはず れた点でも軸上の性質が保たれるという性質がある。そのため系が正弦条件を近似的にも満 足しているかどうかといらことは非常に重要である．もし満足していれば，軸を含む面内で 軸上の結像性をしらべれば充分である，正弦条件については後程ふれるとして，正弦条件を 満足していない例を示す. それは一つの回転楕円鏡による結像である. 数学的に, 一つの焦 点から出た光は他の焦点に集まるが，焦点からずれた点から出る光は一つの点に集まること ができず, 焦点から離れるにつれて像は急速に悪くなる。

もちろん，軸対称でない結像系を使う必要のある場合が多いことと思われる．しかし，そ の場合でも軸対称の系の一部を用いているのか, また正弦条件を満たしているかどらかを知 っておくことは像の状態を知る上で必要なことである.

\section{4. トロイダ系}

上に述べた軸対称で正弦条件を満たす全反射結像系の一つとしてトロイダル系について述 ベる.トロイダル面とは，円弧を直径以外の弦を軸として回転したときできる面である．回 転軸と弧の相対位置により外見上かなり異なったトロイダル面ができる．ここでは入射X線 が面に斜に入射するため, 弦が円弧に非常に近 いトロイダル面を考えることになる。また，正 弦条件を満足させるため軸を共通にした二つの トロイダル面をタンデムに用いる.

第 1 図の(a)，(b)はトロイダル面の軸を含む断 面の上半分, 即ち円弧を示す. $A$ から出た光 (X線）が反射後 $B$ 虚像を作る ${ }^{1)}$. 次に第二の 面で $B$ から出た光が反射後 $C$ に像を作る. $O_{1}$, $\mathrm{O}_{2}$ は鏡の中心で, ここを原点として鏡上の $P$

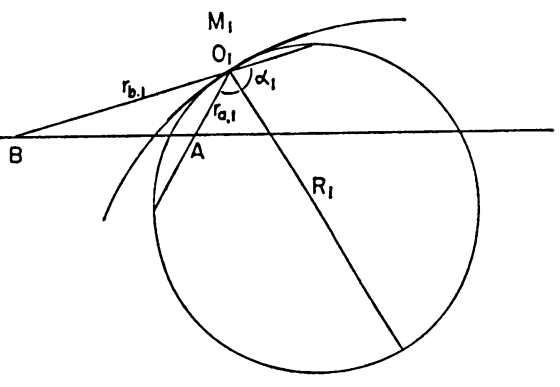

(a)

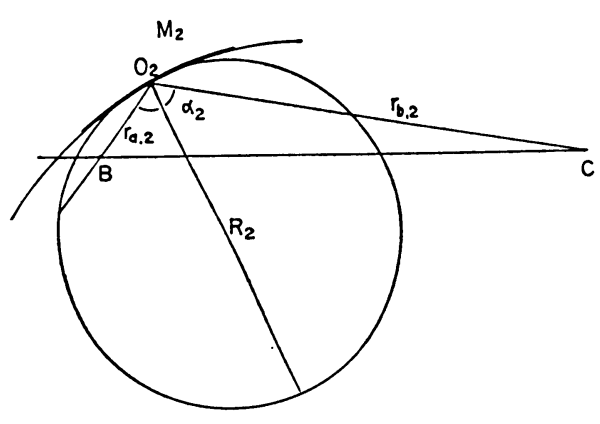

(b)

第 1 図 光路関数の变数を示す. 


$$
\begin{aligned}
F & =F_{1}+F_{2}+F_{3}+F_{4}+\cdots \cdots \\
& =F_{1 \cdot 1}+F_{1 \cdot 2}+F_{2 \cdot 1}+F_{2 \cdot 2} \cdots \cdots
\end{aligned}
$$

ここで

$$
\begin{aligned}
& F_{1.1}=\gamma_{a, 1}+\gamma_{b}, 1 \\
& F_{1.2}=\gamma_{a, 2}+\gamma_{b, 2} \\
& F_{2.1}=\frac{\omega^{3}}{R_{1}^{2}}\left(\frac{R_{1} \sin \alpha}{\gamma_{a}, 1}-1\right) \frac{1}{\left(1-\frac{\omega}{\gamma_{a}, 1}\right)\left(1-\frac{\omega}{\gamma_{b}}\right)} \\
& F_{2.2}=\frac{(-\gamma \omega)^{3}}{R_{2}^{2}}\left(\frac{R_{2} \sin \alpha}{\gamma_{a, 2}}-1\right) \frac{1}{\left(1+\frac{\gamma^{2}}{\gamma_{a}, 2}\right)\left(1+\frac{\gamma_{\omega}}{\gamma_{b, 2}}\right)}
\end{aligned}
$$

$$
F_{8}=0
$$

を得る.この場合， $\omega^{2}$ 項を消す条件として

$$
\begin{aligned}
& \frac{1}{\gamma_{a, 1}}+\frac{1}{\gamma_{b, 1}}=\frac{2}{R_{1} \cos \alpha} \\
& \frac{1}{\gamma_{a, 2}}+\frac{1}{\gamma_{b}, 2}=\frac{2}{R_{2} \cos \alpha}
\end{aligned}
$$

を用いた。この式の導びきかたについては原論文を参照にされたい。また式中の变数につい ては図に示したものを用いた。これらの式の示すように光路関数は $\omega$ の 3 次から始まり, ま た(2)式の示すよらに $F_{2,1}$ と $F_{2,2}$ とは符合が逆であるためこの係数は小さくなる． 即ちあ るい幅のものでもよい像が得られる.

\section{1 正弦条件について}

文字の示すように sine を含んだ式で表わされるが，今の場合にはもら少し変形して次の よらにいい表わすことができる.“光線が面に当たる位置によって倍率が変らない”。いま一 つの面のみの場合を考えてみよう， $\alpha$ は $90^{\circ}$ に近いから, $\sin \alpha=1$ とおいて，

$$
A P=\gamma_{a}, 1-\omega, B P=\gamma_{b, 1}-\omega
$$

倍率 $m_{1}$ は

$$
m_{1}=\frac{B P}{A P}=\frac{-\gamma_{b, 1}-\omega}{\gamma_{a, 1}-\omega}=\frac{-\gamma_{b, 1}}{\gamma_{a, 1}}\left\{1+\left(\frac{1}{\gamma_{a, 1}}+\frac{1}{\gamma_{b, 1}}\right) \omega\right\}
$$

この場合には $\omega$ の值によって $m_{1}$ が变化する，即ち一つの面では正弦条件は満たされない。 次に二つをタンデムに用いると，

$$
\begin{aligned}
& \text { 倍率 }=m_{1} m_{2}=\frac{-\gamma_{b, 1}}{\gamma_{a, 1}}\left\{1+\left(\frac{1}{\gamma_{a}, 1}+\frac{1}{\gamma_{b, 1}}\right) \omega\right\} \frac{\gamma_{b, 2}}{\gamma_{a, 2}}\left\{1-\gamma\left(\frac{1}{\gamma_{a}, 2}+\frac{1}{\gamma_{b, 2}}\right) \omega\right\} \\
& =-m_{1} m_{2}\left\{1+\left(\frac{2}{R_{1} \cos \alpha}-\frac{2 \gamma}{R_{2} \cos \alpha}\right) \omega\right\} \\
& =-m_{1} m_{2}
\end{aligned}
$$

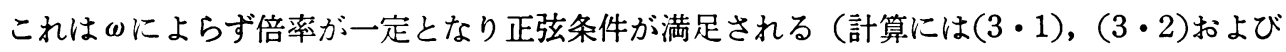
他の条件を代入).

\section{5. 製 作}

以上の理論にもとづき製作を行った。直径 $1 \mathrm{~cm}$ 内外の内面トロイダル鏡を作ることは非 
常にむつかしいため，レプリカ法で外面鏡を作り，そのレブリカを取る方法を用いることに した ${ }^{2)}$. 雄型研磨の方式等については紙面の都合上述べることができないが，タングステン， 超硬度鋼等を用いて型を作り，硬質ガラスでレプリカを取った．表面精度は波長に比例し， 入射の視斜角に反比例する. しかし，AlK $\alpha$ でも理想的には可視光で $\lambda / 30 \sim \lambda / 50$ の精度が必 要で, これは光学研磨でも高精度の部類に属す る.レプリカ法でそこまで行くことは困難で, 今のところ総合的な像の分解能は $1 \mu \mathrm{m}$ である. 理論的には200A〜100A で行くはずであるが， これは今後の技術の問題である.

最後にこの種の鏡として数学的な回転双曲面 と回転楕円面とを組合わせたいわゆる Wolter 型の結像系がある3). 原理的には理想的である が研磨がむつかしい4). その大型のものはX線 望遠鏡としてアポロ宇宙船にのせて太陽のX線 写真を数多くとってきた. その研磨には非常な 努力と時間が払われたようである。しかし，そ の分解能は我々の場合と同じく, 理想的なもの

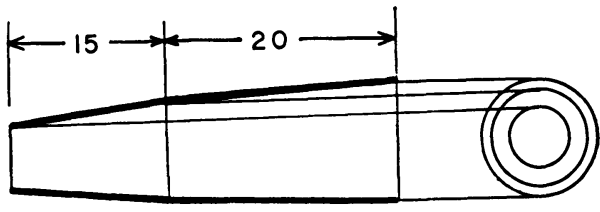

(a)

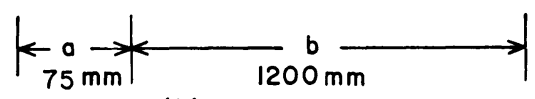

(b)

第2図（a)トロイダル鏡の断面，中心部は stopを㯰いて直接光をさえざる

(b) 結像の位置関係, レンズの式と 同じ. 主面は二つのトロイダル 面の交点. からは遙かに遠い。

1) Y. Sakayanagi : Opt. Acta, 23, 217 (1976).

2) Y. Sakayanagi and S. Aoki : Appl. Opt. 17, 601 (1978).

3) H. Wolter : Ann. Phys. 10, 94 (1952).

4) R. C. Chase and Van Speybroch : Appl. Opt. 12, 1042 (1973).

\title{
多層 X 線ミラーにおける反射率の理論的考察
}

\author{
埼玉工業大学 深町 共栄, 中野 裕司 \\ 山梨大学・教育学部 川 村 隆 明
}

\section{1. はじめに}

シンクロトロン放射光 (SR) から得られるX線は, 通常光源から $10 \mathrm{~m}$ ほど離れた所で使 用される. SR の発散角が $10^{-3} \sim 10^{-4} \mathrm{rad}$ と小さくても $10 \sim 20 \mathrm{~m}$ ほど光源から離れて使用す る所では, ビームスポットの幅が，10 mm 程度と大きなものとなってしまう．このため通常 の単結晶構造解析に用いるような, 直径が数百ミクロン程度の試料に対しては, SR を有効 には利用できない。もし，パスの途中にトロイダルミラーを挿入して，集光を図るならば， 微小試料において SR を有効に使用できる。このような目的のために，実用的なX線ミラ一 を開発することは, SR の有効な利用のために重要な要素であろう. 